\title{
DEVELOPMENT OF NATIONAL ECONOMIES IN THE CONDITIONS OF PANDEMICS
}

\author{
Tetiana Melnyk ${ }^{1}$, Nataliia Mazaraki ${ }^{2}$, Kateryna Pugachevska ${ }^{3}$
}

\begin{abstract}
Among many global problems of mankind, a special place is occupied by the phenomenon of pandemics. A pandemic has been one of the constant companions of human existence since ancient times. This is evidenced by both the texts of religious and mythological orientation, and recorded events in historical life. Pandemic is always an emergency that threatens the very existence of humanity. Various circumstances are heard as the causes of pandemics: sacred (violation of divine laws), domestic (unsanitary conditions of existence), civilizational (technocratic human intervention in the environment), political, economic, etc. The purpose of this article is to study the effects of pandemics that have occurred in different historical periods and their impact on the development of society and the economy. Based on this goal, the objectives of the article are to study the world economy in a pandemic COVID-19; to analyse the trends and forecasts of its further development, including Ukrainian economy; to offer an assessment of the main opportunities and risks of the functioning of Ukraine's economy in quarantine. This article reveals the theoretical and practical principles of the pandemics impact on global economic development. The result of the article is the statistical analysis of pandemic impact on the world economy, which leads to the rupture of economic chains and slowing down the economic and social development for several months or even up to one year. As a conclusion it may be noted, that since periodic pandemics have become an integral part of human life, no country in the world is safe from their direct or indirect impact and, as a result, countries must be economically ready to provide strict measures according to the formula "combating the epidemic - minimizing the negative effects in the short, medium- and long-term periods". Practical implications. The main theoretical propositions, the authors' conclusions presented in the article, are supposed to form a methodological basis in substantiating the priorities of the state support of business in conditions of pandemic and quarantine restrictions. Value/originality. The proposed results can be used for modeling and forecasting the impact of quarantine restrictions on the economic development of countries.
\end{abstract}

Key words: global economy, pandemic, COVID-19, global economy development, national economy, society.

JEL Classification: F12, F13, F41, F43

\section{Introduction}

Among the many global problems of mankind, a special place is occupied by the phenomenon of pandemics. A pandemic has been one of the constant companions of human existence since ancient times. This is evidenced by both texts of religious and mythological orientation and recorded events in historical life. A pandemic is always an emergency that threatens the very existence of humanity. For example, more than 125 million people died from the Plague of Justinian, more than 60 million people died from the "black death" of the 14th century (Lukanova, 2019). Various circumstances can be considered as causes of pandemics: sacred (violation of divine laws), domestic (unsanitary living conditions), civilizational (technocratic human intervention in the environment), political, economic, etc. This indicates that the pandemic phenomenon needs to be

\footnotetext{
Corresponding author:

${ }^{1}$ Kyiv National University of Trade and Economics, Ukraine.

E-mail: t.melnyk@knute.edu.ua

ORCID: https://orcid.org/0000-0002-3839-6018

ResearcherID: https://publons.com/researcher/1673478/tetiana-melnyk/

${ }^{2}$ Kyiv National University of Trade and Economics, Ukraine.

E-mail: n.mazaraki@knute.edu.ua

ORCID: https://orcid.org/0000-0002-1729-7846

ResearcherID: https://publons.com/researcher/2224276/nataliia-mazaraki/

${ }^{3}$ Kyiv National University of Trade and Economics, Ukraine.

E-mail: k.puhachevska@knute.edu.ua

ORCID: https://orcid.org/0000-0002-0473-3119

ResearcherID: https://publons.com/researcher/2227037/kateryna-pugachevska/
} 
comprehensively understood. All mentioned above highlights the relevance of study of the problem of the pandemics impact on the global development of society and the economy.

Among the rather huge range of research sources, the works by S. Shah (Shah, 2016), N. Donthu, A. Gustafsson (Donthu \& Gustafsson, 2020), A. Auzan (Auzan, 2020), and B. Cherkasskii (Cherkasskii, 2008) deserve special attention. American researcher S. Shah in "Pandemic" (Shah, 2016) provides a large-scale canvas of vision of the origins, development, sociocultural, socio-political, socio-economic circumstances of the dynamics of various pandemics.

B. Cherkaskii notes: "The epidemic process, as well as any qualitatively isolated material object, is characterized by specific laws of origin, development and termination, which, however, are subject to more general laws of systemic unity of nature and society" (Cherkasskii, 2008). He formulates a number of laws of the epidemiological process: the first - the law of unity of biological and social, according to which the system of the epidemic process arises and functions as an interaction of two subsystems - biological and social; the second - the law of the ratio of biological and social functions, where the social subsystem is decisive in their relationship, but the biological is not passive; the third - the law of conformity of the biological subsystem to the social subsystem, which indicates the specificity, singularity of the existence of various epidemic processes, changes in the social subsystem cause changes in the biological; the fourth - the law of correspondence in the system of the epidemic process, according to which the more intense the impact of the epidemic process on society and the economy, the more intense is the feedback of targeted measures to eliminate this impact; the fifth - the law of systemic organization of the epidemic process - systemic unity appears in the regular and constant interaction of all levels, subsystems and elements. In addition, scientists studying the problem of pandemics pay attention to the need to separate the concepts of "epidemic" and "pandemic". An epidemic is a massive defeat of a large part of the population or its individual contingents by an infectious disease in a certain time and space. The epidemic contains several concepts: epidemic alarm, epidemic threshold, normative indicator of the disease, explosive epidemic, tardive epidemic, quantitative indicators of the epidemic. A pandemic is a global socio-ecological epidemiological system that ensures the preservation and spread of infection on a global scale. Thus, a pandemic, in contrast to an epidemic, concerns, firstly, the scale (an epidemic exists within one country, a pandemic covers a number of countries), secondly, temporality (an epidemic occurs more often, than a pandemic), and thirdly, the relationship virus transmission (an epidemic can be formed based on a previous virus, a pandemic occurs as a result of a new variant of the virus), fourthly, the speed of spread (epidemic speed is determined by the development of domestic transport infrastructure, pandemic speed - the scale of international vehicles), fifthly, territoriality (the epidemics, that occurred in some countries give the start of pandemics), sixthly, the level of disease (during pandemics it is much higher, than in epidemics), seventhly, the features of completion (the end of the pandemic does not mean the end of the epidemic); eighth, the mortality rate (during a pandemic, it is higher, than in the epidemic from five to ten times).

At the same time, the American researcherJ. Diamond, in his work "Guns, germs, and steel" notes that pandemics and epidemics are the eternal companions of mankind. We coexist forever with viruses on the planet. He compares the advantages of different civilizations, how Europeans managed to break out in technological development (Diamond, 2018). In Fernando Braudel's work, in the first part of "Civilization and Capitalism", much attention is paid to the plague epidemic in the 14th century, how it affected Europe, in particular France (Braudel, 1980).

The research materials of the article consist of quantitative indicators on the impact of the pandemic on the development of economies of leading countries and Ukraine, publications of scientists, who studies the economic consequences of the pandemic in Ukraine and the world, international expert assessments, forecasts etc. A wide range of general scientific and special methods of economic research, including analysis and synthesis, scientific abstraction, generalization, statistical analysis, comparison, systematization is used.

\section{Pandemic as an economic shock}

In recent decades, mass infectious diseases (pandemics) have become more frequent, affecting people's health, social development, and the economies of countries and regions of the world. Thus, in 20082009 , most countries in the world were affected by swine flu, which escalated into the H1N1/09 pandemic. In 2014-2015, West Africa, the United States, and Europe were affected by the Ebola pandemic. The beginning of 2020 was marked by the fastest and most widespread coverage of almost the entire world community by the coronavirus pandemic.

It is obvious, that occurrence of pandemics in this period of time is cyclical with a period of occurrence of approximately five years. In order to analyze the impact of these pandemics on the world economy, the comparison was made on the time axis with the following periodic processes:

- 40-50-year economic cycles of N. Kondratiev, based on changes in technological systems of society;

- 7-11-year cycles of C. Juglar, related to the direction of investment in business; 
- The Dow Jones Industrial Average, which reflects the total capitalization of the 30 largest US companies.

In 2020-2021 the downward wave of the 5 th Kondratiev cycle ends; this, with the transition to the next technological mode, switches to the upward wave of the 6th Kondratiev cycle. This indicates the objective conditions for further long-term recovery of the world economy. At the same time, the start of this rise in the period 2020-2021 is significantly weakened by the rupture of traditional economic chains as a result of the coronavirus pandemic, a significant "dispersion" (focus) of investment in various businesses (both obsolete and promising), which leads to the next bottom of the Juglar cycle and a fall of $30-40 \%$ of the Dow Jones index. According to Juglar, this decline should last for about a year, during which investments will be redirected to the 6th mode technologies. After exceeding the contribution to world GDP by more than 5-7\% due to the technologies of the 6th system, the rise of the global economy should begin according to both Kondratiev and Juglar.

Similar recessions in the world economy have been observed before. They arose, inter alia, under the influence of pandemics of influenza and swine flu in 2008-2009 and Ebola in 2014-2015, respectively. But they had a short-term impact on the world economy (from a few months to a year), after which its objective development continued with elements of renewal and partial elimination of artificial layers (financial bubbles, pyramids, etc.). Extrapolating the phenomena of 2008-2009 and 2014-2015 to the current situation with the coronavirus pandemic, we can make a predictive judgment, that the global economic downturn in 2020 will be deeper than the previous crises, but in 2021-2022, after overcoming the new pandemic and getting rid of obsolete and artificial layers, will begin its renewal and growth in accordance with the objective laws of economics.

\section{Findings}

According to the World Bank research, since 1870 the world economy has experienced 14 global recessions. Current forecasts mean, that the global downturn due to COVID-19 will be the fourth deepest in this period and the worst since the end of the World War II. There is expected the decline of GDP and, accordingly, GDP per capita in the vast majority of countries (Figure 1).

Figure 2 confirms the negative effects of the COVID-19 pandemic and, in particular, the share of the world's economies in a recession, defines as an annual reduction in GDP per capita. Sample includes 183 economies, though the sample size varies significantly by year.

The negative consequences of the coronavirus pandemic have also affected the economy of Ukraine (Figure 3). In 2020, the GDP level is expected to fall by $3.5 \%$, which is $1.7 \%$ less, than the world level $(-5.2 \%)$.

In 2020, compared to the previous decade, there is a negative trend in all regions of the world in the inflow of FDI to countries with growing markets, including Ukraine.

Analysis of quantitative and qualitative changes in the world economy showed that the COVID-19 pandemic forced states to introduce quarantine measures - closed state borders, suspended transport links, suspended the activities of a large number of enterprises, introduced restrictive measures for business. As a result, the world economy is plunged into a deep recession - it is projected, that by the end of 2020 , the countries with the most stable economies will lose at least $2.4 \%$ of their GDP. The forecasts of world GDP growth rates for 2020 have also been reduced from $2.9 \%$ to $2.4 \%$.

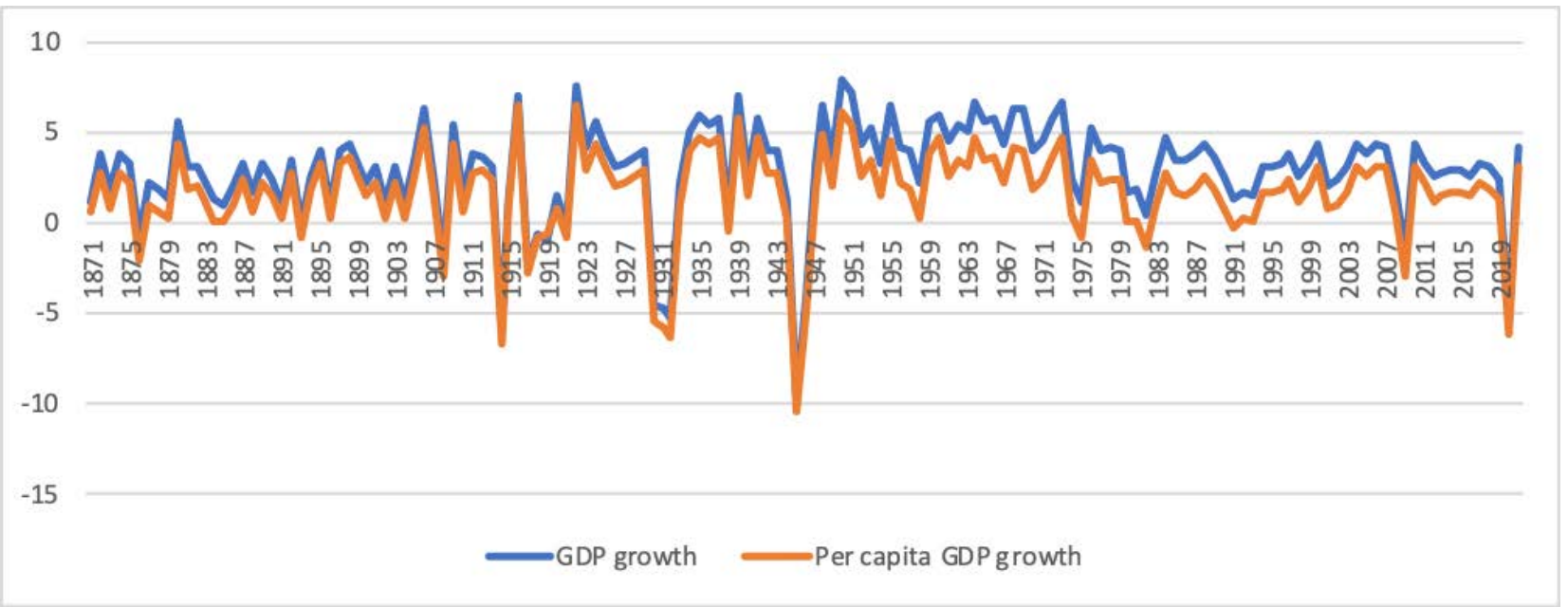

Figure 1. Growth of world GDP and GDP per capita in 1871-2021, \%

Source: conducted by the authors on the basis of the World Bank data 


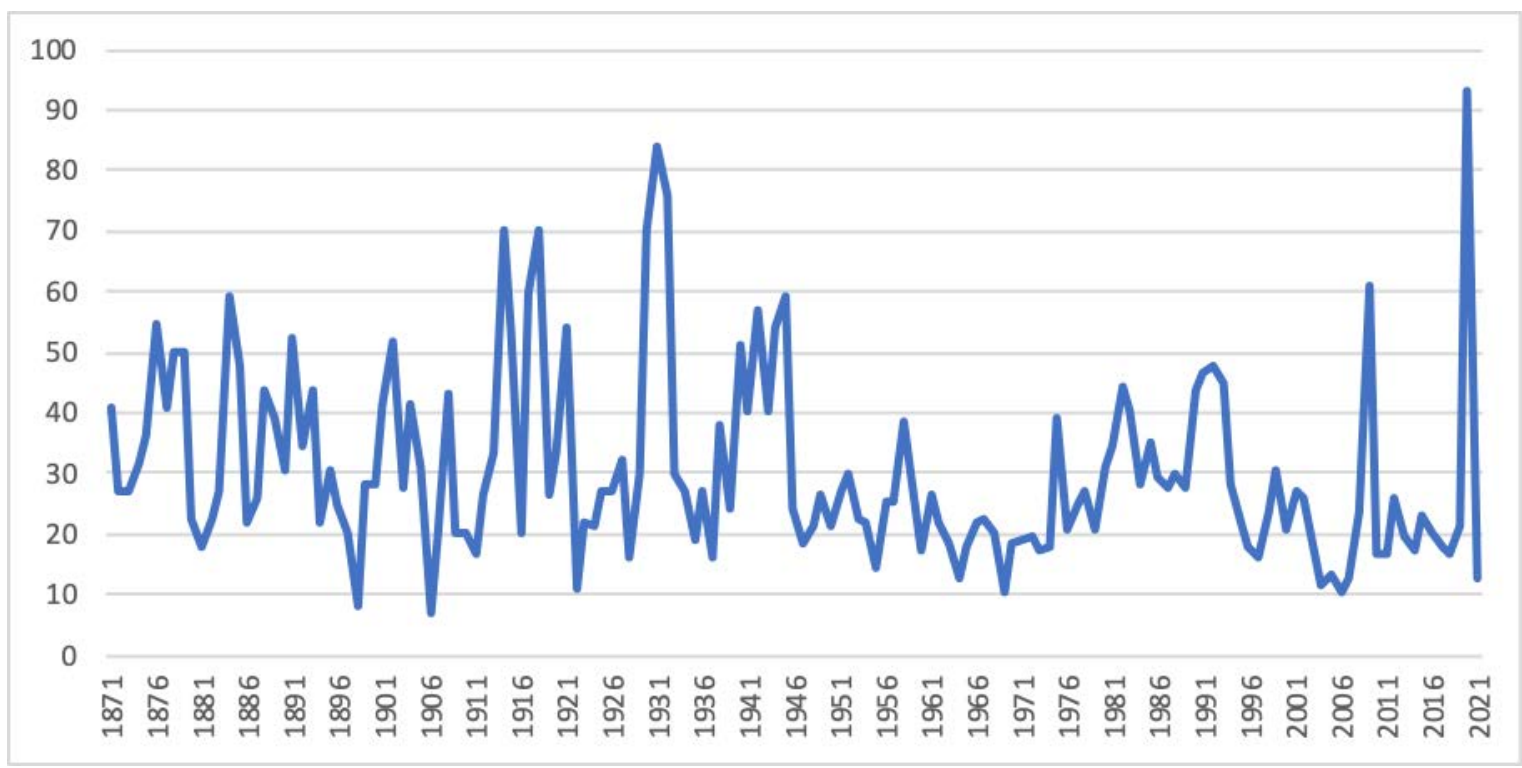

Figure 2. World economies during the recession (annual reduction in GDP per capita)

Source: conducted by the authors on the basis of World Bank data

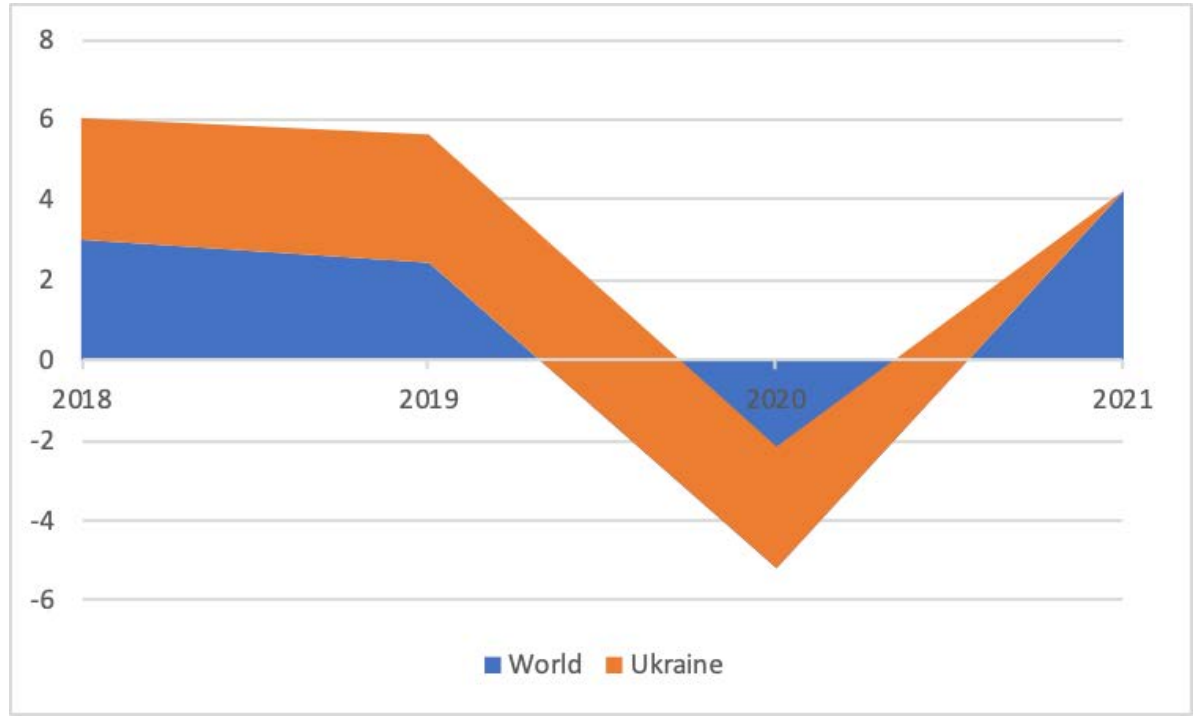

Figure 3. GDP growth rates in the world and in Ukraine

Source: conducted by the authors on the basis of World Bank data and State Statistics Service of Ukraine

Declining consumer demand in the European Union and the United States will have a negative impact on imports from developing countries. The economies of all countries will feel the effects of reduced world production, disruption of trade chains, reduced investment. In the current conditions, the quarantine measures in China will have a great impact on the world economy, as the production facilities of many industrial and innovative companies of the world are located on the territory of this country. The closure of plants and factories, as well as a decrease in demand for Chinese products will have a negative impact on the profits of such companies (Figure 4).
The complete or partial shutdown of a number of enterprises also had a negative impact on the global labor market - about $80 \%$ of the world's working population was affected by the COVID-19 pandemic (Figure 5). According to the International Labor Organization, in the second quarter of 2020, the total number of man-hours worked is expected to decrease by $6.7 \%$, which is equivalent to the full employment of 195 million people (World Data Center for Geoinformatics and Sustainable Development, 2020).

Employees of such industries as arts and entertainment, transport services, hotel and tourism business, real estate trade, and industrial production are 


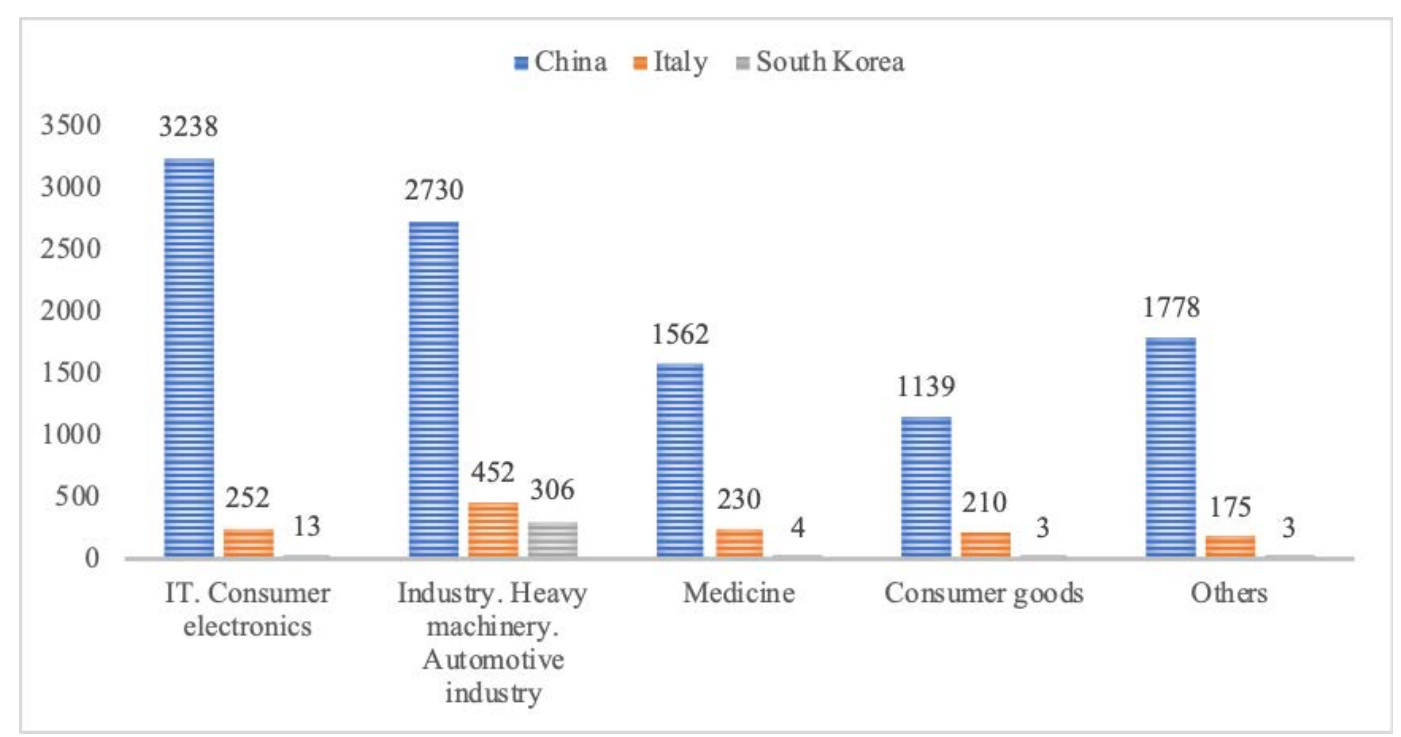

Figure 4. Objects of the 1000 largest companies in the world in quarantine zones

Source: conducted by the authors on the basis OECD statistics

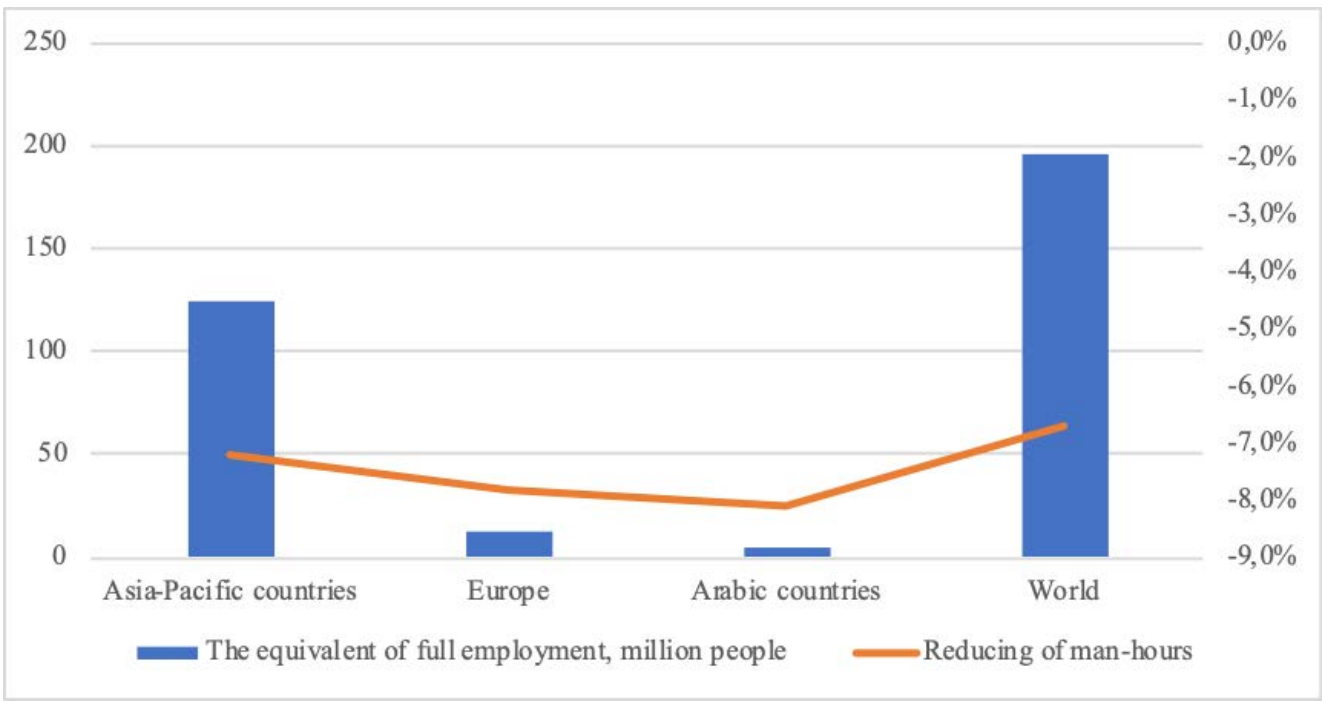

Figure 5. Reduction of employment in the second quarter of 2020

Source: conducted by the authors on the basis of Kreston research

most at risk of layoffs. While employed in education, health care, agriculture, utilities are less affected by negative trends.

As for industries, tourism is one of the most affected industries. The expected reduction in revenues in this area is 116.5 billion USD, the main reason was the restriction of movement between countries. The World Travel and Tourism Council estimates, that COVID-19 could cause the loss of about 50 million jobs in the industry. It is noted, that the expected recovery of the industry will take place no earlier than in the IV quarter of 2020 (McKinsey \& Company, 2020). In an attempt to compensate for the losses, a number of travel companies have already announced the start of online booking of tours for 2021. However, their prices significantly exceed the level of 2019, which, accordingly, has a negative impact on the already low demand for these services. Also, significant losses are borne by airlines; the demand for their services has dropped to zero under quarantine. The expected revenue reduction is 252 billion USD, $44 \%$ compared to 2019 (International Air Transport Association, 2020), the reason for this fact is the restriction of transport links. In order to minimize losses, airlines introduce a preferential policy to change the date of booking tickets or cancel the reservation. Carriers are also reducing the size of the fleet and using aircraft designed for a small number of passengers. Crisis phenomena have been noted in the automotive industry, which is due primarily to the fact that about $80 \%$ of the world supply chain in 
this industry, in one way or another, is associated with China. According to Counterpoint, global demand for cars is expected to decline by $7 \%$, due to disruptions in the supply of spare parts from China, disruptions in production in Europe, the closure of car assembly plants in the United States (Counterpoint, 2020).

However, not all industries suffer losses - a number of companies have managed to maintain a stable position in the market and to significantly increase their revenues. Positive dynamics were discovered in the following directions:

1. E-commerce. Under current circumstances, people spend most of their time at home, which has had a corresponding effect on consumer behavior - thus, preference is given to online-shopping. Examples of successful companies in this situation are: Amazon, Ocado, JD.com.

2. Pharmaceuticals. The efforts of the world's leading pharmaceutical companies are focused primarily on the development of a vaccine against COVID-19. Also an important aspect of their activitiy is the timely supply of the required quantities of drugs, used for the treatment of people affected by the virus. During a pandemic, successful companies in this field are Gilead, Moderna, Roche, Fujifilm, Pfizer.

3. Delivery services. In addition to the existing large players, HoReCa representatives are increasing their share in this market - restaurants and cafes deliver ready meals to their customers with the help of couriers. The logistics division of Alibaba Group, Cainiao, Deliveroo became successful during this period.

4. Video communication services. In an environment, where most white collars have to move on to remote working, conferencing services have become very popular. In addition to sales growth, there is also an increase in capitalization of companies in this industry. The most successful representatives are: Zoom, Webex (Cisco), Skype (Microsoft).

5. Entertainment and gaming services. The inability to spend leisure time in cinemas and entertainment centers encourages people to increasingly use similar services online.

Governments around the world are committed to creating and implementing economic programs (fiscal stimulus) aimed at mitigating the effects of the COVID-19 pandemic and stabilizing the economy. The largest one is the program adopted by the US government - its financing amounted to 2.3 trillion USD (about $11 \%$ of GDP). Additionally, the topfive countries in terms of such economic programs funding include Germany, China, Canada and Australia (Counterpoint, 2020).

As for the Ukrainian economy, analysts estimate the losses accumulated during the month of quarantine restrictions at 120 billion UAH, which can be compared with the annual budget for health care for year 2020 (113.3 billion UAH). First of all, the losses were carried due to the shutdown of a number of sectors of the economy. According to a survey by the Society of Ukrainian Entrepreneurs, in collaboration with the Ukrainian Marketing Group, a third part of Ukrainian companies was forced to suspend their quarantine activities, while $6 \%$ closed their businesses completely. If the quarantine in the country lasts more than 3 months, more than $60 \%$ of Ukrainian companies will be threatened with bankruptcy (Ukrainian Entrepreneurs Union, 2020).

Ukrainian business, which is still functioning, has also faced a number of difficulties. As a result, the labor market has suffered significantly - according to the Chamber of Commerce of Ukraine, the number of unemployed during the quarantine period has doubled. In the nearest future, Ukraine's economic losses will increase under the influence of declining purchasing power of the population - now more than half of Ukrainians have already felt the effects of quarantine measures.

From the point of current situation, the government has updated the forecast of key macroeconomic indicators for 2020. According to the forecast made in autumn 2019, the country's GDP was expected to reach 4.5 trillion UAH in 2020. However, the pandemic reduced the anticipated figure to 4 trillion UAH. The inflation forecast of $8.7 \%$ is estimated by experts as quite pessimistic: economists and analysts tend to believe that the final figure might be at $5 \%$. Unemployment is expected to rise by $1.3 \%$ but the IMF gives a more pessimistic forecast - by the end of the year the figure will be equal to $10.1 \%$. The average level of wages is also expected to decline, but taking inflation into account, it is expected to be close to the level of 2019. Possible devaluation of hryvnia is estimated at $11 \%$ of last year's exchange rate, however, if quarantine measures are extended, the exchange rate may reach 35 UAH for 1 USD.

The COVID-19 pandemic will affect all sectors of the economy to varying degree. It is expected, that significant losses will be avoided in industries related to the production and supply of food, pharmaceutical industry, IT industry. The most sensitive sectors accumulate about $40 \%$ of GDP and employment. Moreover, more than half of companies in these industries are provided with means, that allow to operate in quarantine circumstances for no more than 2 months.

\section{Conclusions}

The COVID-19 pandemic has affected all sectors of the world economy with no exceptions. Quarantine restrictions in the context of the COVID-19 pandemic have had a negative impact on established global supply chains, and this fact will contribute to the global trend of transition from free foreign trade to protectionist policies. The world's leading companies 
are already thinking about transforming their strategy in terms of supply chain optimization and localization of production with maximum added value. As for migration phenomenon, the spread of viral infection will allow a number of countries to strengthen migration policy. Nevertheless, more and more EU leaders are in favor of revising the Schengen agreement. As for the United States, even before the pandemic, protecting the American labor market from migrants was identified as an important task set by the US government. Restrictions will affect labor mobility, and rising unemployment will not contribute to wage growth. Business processes will be maximally digitized, the role of electronic documentation management will grow, as well as software aimed at automatizing the activities. Companies will expand their workforce capacity for remote working, which will save on office maintenance. Thus, the optimization of organizational structures of companies is expected - part of the management levels will cease. The role of business communication with the help of video communication services (Zoom, Webex) will increase, in turn, the need in personal meetings will decrease. This will significantly affect the services of passenger air transportation and the hotel industry, as the number of business trips will be significantly reduced. The partnership between business and the state will become more significant. Government will become more interested in large investment projects, being involved in the process of business design and planning, because employment growth, stable tax collection and social development of the territory are the main priorities in a crisis. Authorities will focus precisely on developing and implementing business support and development programs. Currently, the world's leading companies are directing main forces towards adapting their activities to quarantine-related limitations, saving workplaces and minimizing their losses due to the recession.

The Ukrainian economy is now experiencing a reduction in GDP, a complete or partial shutdown of enterprises, a sharp rise in unemployment - all these aspects are the consequences of COVID-19. Therefore, the prospects for further research should focus on creating effective conditions for the functioning and development of the national economy in the postcrisis period. What incentives should be provided to companies for their support by the state? What steps should the country take to accelerate the recovery from the economic crisis that resulted from the COVID-19 pandemic?

\section{Acknowledgements}

The article is prepared within the framework of the Scientific research work "The potential of import substitution in Ukraine on conditions of post industrial economy formation" (state registration number 0119U100625) and "Trade and economic wars: national and international dimension" (state registration number 0118U000130)

\section{References:}

Auzan, A. A. (2020). The economy under the pandemic and afterwards. Population and Economics, 4(2), 4-12. doi: $10.3897 /$ popecon.4.e53403

International Air Transport Association (2020). Retrieved 24 October, 2020 from https://www.iata.org/en/ publications/economics/

Chamber of Commerce and Industry of Ukraine (2020). Retrieved 24 October, 2020 from https://ucci.org.ua/ press-center/ucci-news/diznaitesia-bilshe-pro-zmini-v-torgovelnii-polititsi-inozemnikh-krayin-u-zviazku-izcovid-19

Cherkasskii, B. L. (2008). Globalnaia epidemiologiia [Global epidemiology]. Moscow: Praktycheskaia medytsyna. (in Russian)

Donthu, N., \& Gustafsson, A. (2020). Effects of COVID-19 on business and research. Journal of Business Research, 117, 284-289. doi: 10.1016/j.jbusres.2020.06.008

Braudel, F. (1980). Civilization and Capitalism, 15th-18th Century. Reed Business Information, Inc.

Diamond, J. (1997). Guns, Germs and Steel. Jonathan Cape.

Kreston (2020). COVID-19 and the world economy: can't it be saved? Retrieved 15 September, 2020 from: https://kreston-gcg.com/en/covid-19-ta-svitova-ekonomika-vryatuvati-nemozhlivo-likviduvati/

Lukanova, V. V. (2019). Pandemic as an antisystem: analysis of constitutive aspects. Retrieved 24 October, 2020 from: https://journals.indexcopernicus.com/api/file/viewByFileId/833725.pdf

Shah, S. (2016). Pandemic. St. Martin's Press, Sarah Crichton Books/Farrar, Straus \& Giroux, New York, NY, USA. Tkalenko, S., Melnyk, T., \& Kudyrko, L. (2020). Macroeconomic factors influencing the development of Ukraine's foreign trade. Baltic Journal of Economic Studies, 6(3), 143-155. doi: 10.30525/2256-0742/2020-6-3-143-155

World Data Center for Geoinformatics and Sustainable Development (2020). Retrieved 15 August, 2020 from http://wdc.org.ua/uk/node/190016

Cabinet of Ministers of Ukraine (2020). Retrieved 24 October, 2020 from https://www.kmu.gov.ua/news/ programa-stimulyuvannya-ekonomiki-dlya-podolannya-naslidkiv-covid-19-ekonomichne-vidnovlennya 
International Labor Organization (2020). Retrieved 24 September, 2020 from https://www.ilo.org/global/ statistics-and-databases/lang--en/index.htm

OECD statistics (2020). Retrieved 24 September, 2020 from https://www.statista.com/studies-and-reports/ regions-and-countries

World Travel and Tourism Council (2020). Retrieved 24 September, 2020 from https://wttc.org/Research/ Economic-Impact/Recovery-Scenarios-2020-Economic-Impact-from-COVID-19

McKinsey \& Company (2020). Retrieved 29 September, 2020 from https://www.mckinsey.com/industries/ travel-logistics-and-transport-infrastructure/our-insights

Counterpoint (2020). Retrieved 27 October, 2020 from ttps://www.counterpointresearch.com/data/

State Statistics Service of Ukraine (2020). Retrieved 29 October, 2020 from http://www.ukrstat.gov.ua/

Union of Ukrainian Entrepreneurs (2020). Retrieved 29 October, 2020 from https://sup.org.ua/uk

The World Bank statistics (2020). Retrieved 30 October, 2020 from https://www.worldbank.org 